\title{
In vivo skin fluorescence imaging in young Caucasian adults with early malignant melanomas
}

This article was published in the following Dove Press journal:

Clinical, Cosmetic and Investigational Dermatology

22 August 2014

Number of times this article has been viewed

\author{
Gérald E Piérard' \\ Trinh Hermanns-Lê ${ }^{2}$ \\ Sébastien L Piérard ${ }^{3}$ \\ Lucas Dewalque ${ }^{4}$ \\ Corinne Charlier ${ }^{4}$ \\ Claudine Piérard- \\ Franchimont ${ }^{2}$ \\ Philippe Delvenne ${ }^{2}$ \\ 'Laboratory of Skin Bioengineering \\ and Imaging (LABIC), Department of \\ Clinical Sciences, Liège University, \\ ${ }^{2}$ Department of Dermatopathology, \\ Unilab Lg, University Hospital \\ of Liège, ${ }^{3}$ NTELSIG Laboratory, \\ Montefiore Institute, University \\ of Liège, ${ }^{4}$ Department of Clinical, \\ Forensic and Environmental \\ Toxicology, University Hospital \\ of Liège, Liège, Belgium
}

Correspondence: Gérald E Piérard Laboratory of Skin Bioengineering and Imaging (LABIC), Department of Clinical Sciences, University of Liège, 4000 Liège, Belgium

$\mathrm{Tel}+3243662408$

Fax +32 43662976

Email gerald.piérard@ulg.ac.be
Background: Human cutaneous malignant melanoma (CMM) is an aggressive cancer showing a dramatic worldwide increase in incidence over the past few decades. The most prominent relative epidemiological increase has been disclosed in young women. The aim of the study was to assess the effects of chronic sun exposures in order to rate the extend of melanocytic stimulations in the vicinity of CMM.

Methods: The study was designed to evaluate the melanin distribution and density using ultraviolet light illumination. The present study was performed on surgical excision specimens of thin CMM lesion removed from the upper limbs of 55 Caucasian adults ( 37 women and 18 men). Two control groups comprised 23 men and 21 women of similar ages who had mediumsize congenital melanocytic nevi, also present on the upper limbs. The peritumoral skin was scrutinized using a Visioscan ${ }^{\circledR}$ VC98 device, revealing the faint mosaic melanoderma (FMM) pattern that grossly indicates early signs of chronic photodamage in epidermal melanin units. Results: The median extent of relative FMM was significantly higher in the CMM male group. By contrast, the CMM female group showed a reverse bimodal distribution in FMM size. Only $12 / 37$ (32.5\%) of the CMM female group had an increased FMM size, whereas 25/37 (67.5\%) of females with CMM had a global FMM extent in the normal range, relative to the controls. Conclusion: Thin CMM supervening in young women appear unrelated to repeat photoexposure. Other mechanisms are possibly involved.

Keywords: gender, HOX gene, ULEV method, genotoxicity, faint mosaic melanoderma

\section{Introduction}

The worldwide increase in epidemiological incidence of cutaneous malignant melanoma (CMM) in Caucasians over the past decades is possibly genuine and/or related to multiple close screenings in individuals with light complexion. Obviously, the risk markedly varies according to the combination of both the ethnic skin pigmentation and individual behavior regarding ultraviolet light (UVL) exposure. ${ }^{1-6}$ CMM commonly occurs at a relatively young age, particularly between the ages of 15 and 34 years. ${ }^{5,6}$ CMM is generally more common in women than in men (sex ratio 2:1) but carries a better prognosis for affected women. In some Caucasian populations of Western Europe, the rising incidence of CMM over the past decades has particularly affected women during early adulthood..$^{-10}$ The cause for such sex- and age-related CMM risk remains presently unsettled. Environmental factors, including UVL exposure from the sun and tanning sunbeds ${ }^{4}$ could be suspected, but the role of some chemical xenobiotics, particularly hormonal disruptors, ${ }^{11-13}$ is not ruled out.

Chronic exposure of the epidermis to UVL induces an increased production of melanin by melanocytes and its transfer to neighbor keratinocytes in each epidermal melanin 
unit. ${ }^{14}$ Such activation is responsible for the presentation of faint mosaic melanoderma (FMM), particularly evident in Caucasian skin. ${ }^{15-20}$

The acquired discrete uneven skin pigmentation forming the FMM pattern is a hallmark of photoaging. ${ }^{16-21}$ Once delivered by melanocytes to keratinocytes, melanin acts, in part, as a UVL filter. However, according to individual parameters, including the phototype, age, and previous cumulative UVL exposures, skin presents distinct FMM appearances. ${ }^{16,19,21}$ The diverse patterns of age-related FMM is conveniently disclosed and magnified using computerized UVL enhanced visualization (ULEV) $)^{17-20}$ - a charge-coupled device (CCD) camera equipped with an internal UVL-emitting unit is suitable for precise quantification of the epidermal melanin content. The increased contrast between the FMM and the rest of the skin is the combined result of: a) the greater reflection of UVL wavelengths than visible light by dermal fibers, and $b$ ) the greater UVL absorption by epidermal melanin. ${ }^{18,22}$ Any other UVLabsorbing or -reflecting structure interposed above the dermal fibrous networks likely will alter the ULEV reading. In previous observations, some individuals have exhibited rare and discrete foci of nearly total depigmentation; ${ }^{18-21}$ the focal amelanotic skin appeared as white iridescent skin ivory spots.

The aim of this study was to explore the ULEV findings in the skin of young adults suffering from a superficial CMM.

\section{Materials and methods}

The present observational laboratory study was performed in accordance with the Declaration of Helsinki. The noninvasive observations were conducted on surgical skin samplings addressed to our laboratory with the understanding and consent of the patients.

The material consisted of surgical skin excision specimens of CMM that was diagnosed by dermatologist members of the Mosan Group for the Study of Pigmented Neoplasms. The lesions corresponded to "thin" ( $<1 \mathrm{~mm}$ thick) early CMM that developed on the upper limbs of phototype III and IV Caucasian subjects. ${ }^{3}$ The patients were 37 women aged 21-29 years and 18 men aged 23-27 years. Two control groups were formed by 23 men and 21 women in whom a congenital melanocytic nevus had been excised from the upper limbs, aged 21- to 29-years old. Upon arrival in the laboratory, the samples were examined. In particular, the peritumoral skin, corresponding to the surgical security margins around CMM, was observed using a Visioscan ${ }^{\circledR}$ VC 98 UVA-light video camera (Courage + Khazaka Electronic GmbH, Cologne, Germany). The video sensor chip was closely applied to the skin. The probe consisted of a CCD camera emitting a beam of UVL and near-UVL. Part of the incident light was reflected and scattered at the skin surface, corresponding to specular light reflectance (SLR). This was detected by the CCD camera, although it remained invisible to the naked eye. SLR observation was noninvasive, ethical, and applicable without any restriction on the human samplings. The instrumental procedure provided objective information.

The uniform skin illumination provided by the Visioscan brought out a sharp picture of a $6 \times 8 \mathrm{~mm}$ area of the skin surface. The high image resolution allowed close assessments of the subclinical skin pigmentation. The connection of the Visioscan to an image digitalization unit configured the image to a ULEV with resolution of $512 \times 400$ pixels and 256 gray levels, where 0 corresponded to black and 256 was indicative for white. Skin ULEV revealed signs of discrete melanoderma presenting as a patchwork of speckled darker dots and larger globular macules. ${ }^{16,18,19}$ The patterns of darker FMM spots did not show up well under regular white light examination. The percentage area covered by the FMM was considered to be related to the impact of cumulative UVL exposure on epidermal melanin units. ${ }^{20}$

Dark areas of FMM were assessed by evaluating all spots, irrespective of their individual sizes. The global area was measured and the median global area (A) value was calculated. Sex differences were assessed using the nonparametric Mann-Whitney paired test applied to the A measures found for the CMM and nevi, respectively. A $P$-value lower than 0.05 was considered statistically significant. In addition, the individual A values were expressed as percentages of the total skin area scrutinized by the Visioscan probe. The distribution of these values in each group of subjects was determined on histograms, in a scale of 5\% steps. This procedure served to determine the modes of data distribution.

The neoplasms were examined by routine optical microscopy on hematoxylin and eosin sections. The CMM thickness was measured for each lesion. In addition, tumoral growth was assessed with Ki-67 immunostaining (Dako Denmark A/S, Glostrup, Denmark). ${ }^{23}$ The percentage of positive nuclei among tumoral cells was assessed. Statistical comparisons between the four groups of patients were performed using the chi-square test. A $P$-value lower than 0.05 was considered statistically significant.

\section{Results}

The thickness of all CMM lesions ranged from 0.18 to $0.69 \mathrm{~mm}$. No significant differences were disclosed between the two sexes. The CMM Ki-67 index ranged from $6.3 \%-13.8 \%$, and no significant differences were yielded 
between the sexes. The Ki67 index was lower than 3\% in each nevus, without any significant differences between sexes. A significant difference $(P<0.01)$ was yielded between the $\mathrm{Ki}-67$ indices in CMM and nevi. The macroscopic aspect of the peritumoral skin looked normal at the visual inspection.

Globally, FMM was present in the peritumoral skin of all samples (Figure 1), but its extent, as indicated by A value, was not similar among subjects. High FMM A values were exclusively found in CMM patients. In 1/37 female CMM lesions, from a woman with intense FMM, a skin ivory spot was disclosed among the darker FMM dots. Data are presented in Figure 2. No significant difference was yielded between the FMM A values in the two control groups. By contrast, the FMM A value was significantly $(P<0.01)$ larger in men with CMM than in the other groups.

The data regarding the distribution of patients (\%), with respect to the median A values of FMM in the peritumoral skin, are presented in Figure 3. The data distributions were unimodal, with low FMM A values in both sex groups with melanocytic nevi. The group of male CMM showed a quite distinct distribution of FMM A values, with a prominent mode corresponding to high A values, and a discrete mode of lower FMM A values with a range similar to that seen in the melanocytic nevi. The FMM A values were similar to the skin around melanocytic nevi in 25/37 (67.5\%) of female CMM lesions; whereas the remaining 12/37 (32.5\%) female CMM lesions showed significantly $(P<0.05)$ higher FMM $A$ values. This latter group had a FMM range of A values similar to that of most male peri-CMM skin.

\section{Discussion}

Several risk factors support the development of human CMM. The deleterious effects of UVL on the skin have been

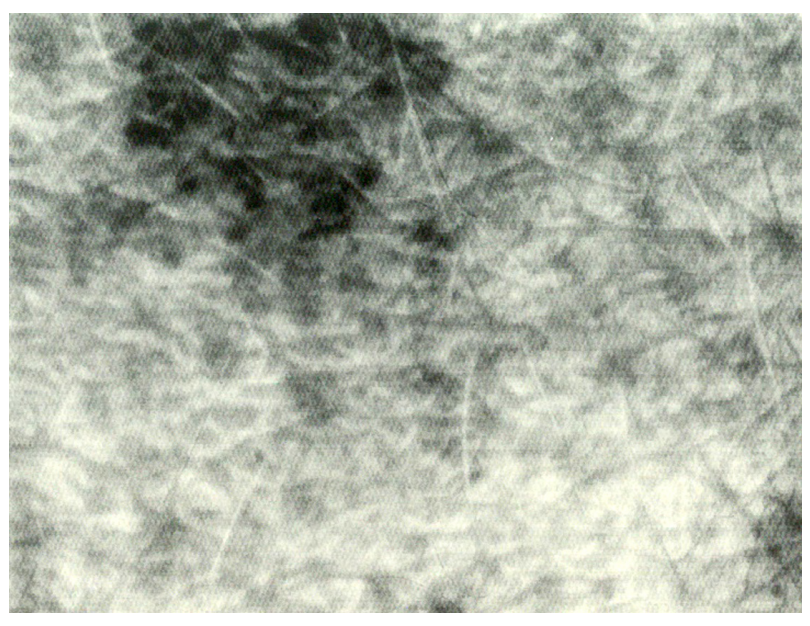

Figure I Example of faint mosaic melanoderma. studied extensively, due to the physiological and pathological implications of natural and recreational exposure to solar and nonsolar UVL sources. The causative role of UVL in melanoma has been thoroughly investigated. ${ }^{24-28}$ The solar UVL spectrum spans from 100 to $400 \mathrm{~nm}$ wavelength and is conventionally stratified into UVA (320-400 nm), UVB (280-320 nm), and UVC (100-280 nm). Of note, UVL of wavelengths shorter than about $310 \mathrm{~nm}$ are absorbed by the earth ozone layer; hence, natural exposure to UVC from solar radiations is minimal. Approximately $90 \%-95 \%$ of UVA and $5 \%-10 \%$ of UVB from solar radiation reach the human skin. ${ }^{24}$ UVA can penetrate deep into the dermis. About $20 \%-50 \%$ of solar UVA and only $9 \%-15 \%$ of solar UVB reach the skin melanocytes.

Only young Caucasian adults from Western Europe were enrolled in the present study. They had a thin CMM lesions with a limited germinative compartment, corresponding to tumor with a slow growing pattern..$^{29,30}$

Geographical differences in bioactivity, strength, and seasonal distribution of UVA and UVB have been reported in the past, but the influence of these differences on human skin pigmentation is not clearly identified. For example, latitudinal variations in UVA distribution are wider than for UVB, and higher UVA levels predominate toward the poles. Western Europe receives a higher UVA amount compared with UVB, whereas equatorial regions receive slightly less UVA than do tropical and subtropical areas. UVA wavelengths reach the dermal layers of the skin, and their effects on photoaging and keratinocyte invasiveness are well established. ${ }^{28}$ In particular, melanocytes appear to be typically susceptible to the damaging effects of UVA.

UVL exposure undoubtedly plays a role in the development of CMM, but its involvement is not as clear-cut as for other skin cancers, such as squamous cell carcinoma. More risks appear to be associated with intermittent/recreational than with occupational/continuous sun exposure. However, the emphasis on "sun burning" as a cause, rather than a risk factor, is likely misplaced. Thus, for the development of CMM, the most risky sun-related activity for adults is currently thought to be a fortnight holiday with intense sun exposure. The heterogeneity in FMM influences the global photoreactivity of the skin. ${ }^{31}$ Although melanin-enriched FMM spots protect local epidermal cells from UVL, the foci with lower melanin content and the skin ivory spot foci are much less protected. ${ }^{32}$ None of the previous studies using the ULEV technology pointed to sex differences in similarly aged individuals in the FMM patterns, and the same finding was observed in the two control groups of the present study. 


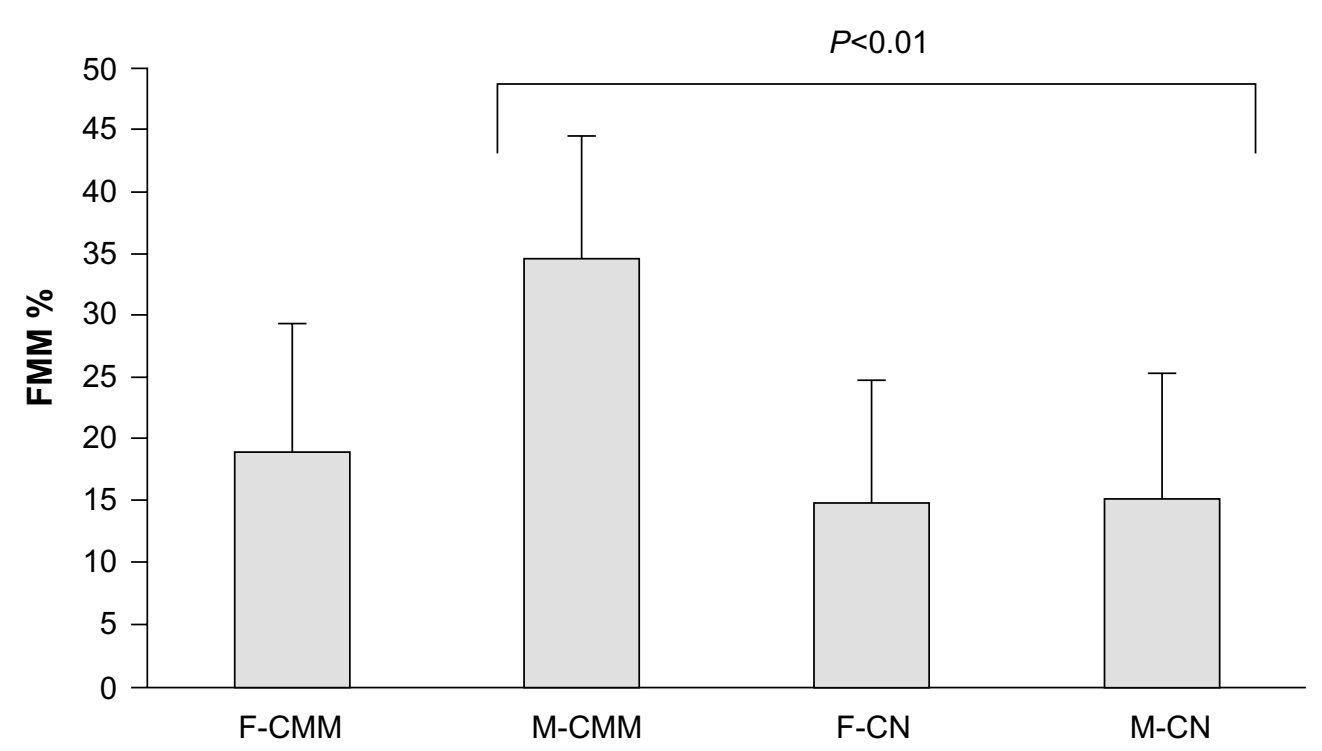

Figure 2 Mean and standard deviation of the extent (\%) of FMM in female and male subjects suffering from thin CMM or a congenital melanocytic nevus. Note: The FMM global area was significantly $(P<0.01)$ larger in men with CMM.

Abbreviations: CMM, cutaneous malignant melanoma; CN, congenital melanocytic nevus; F, female; FMM, faint mosaic melanoderma; M, male.

The situation appeared somewhat different in young adults with CMM. The FMM pattern in men with CMM appeared more heterogeneous, with a majority showing a FMM extent larger than the range found in controls. By contrast, about two-thirds of the FMM A values in young Caucasian women with CMM remained in the range found in controls.

It is acknowledged that FMM is nearly absent during childhood and progressively increases during early adulthood in the Caucasian population. It is possible that the combination of hormonal changes and repeat UVL exposures is responsible for the FMM extension. Quantification of the number, size, shape, and clustering of the melanoderma spots has been reported to be related to the number of nonmelanoma skin cancers in the older population. ${ }^{17}$

Skin photoprotection primarily depends on the uppermost keratinocytes, with the melanin pigment-producing melanocytes present in the basal layer of keratinocytes. Melanin is synthesized in the melanocytes and helps protect the skin from the deleterious effects of solar radiation, by several mechanisms. ${ }^{33}$ Accordingly, patients with impaired

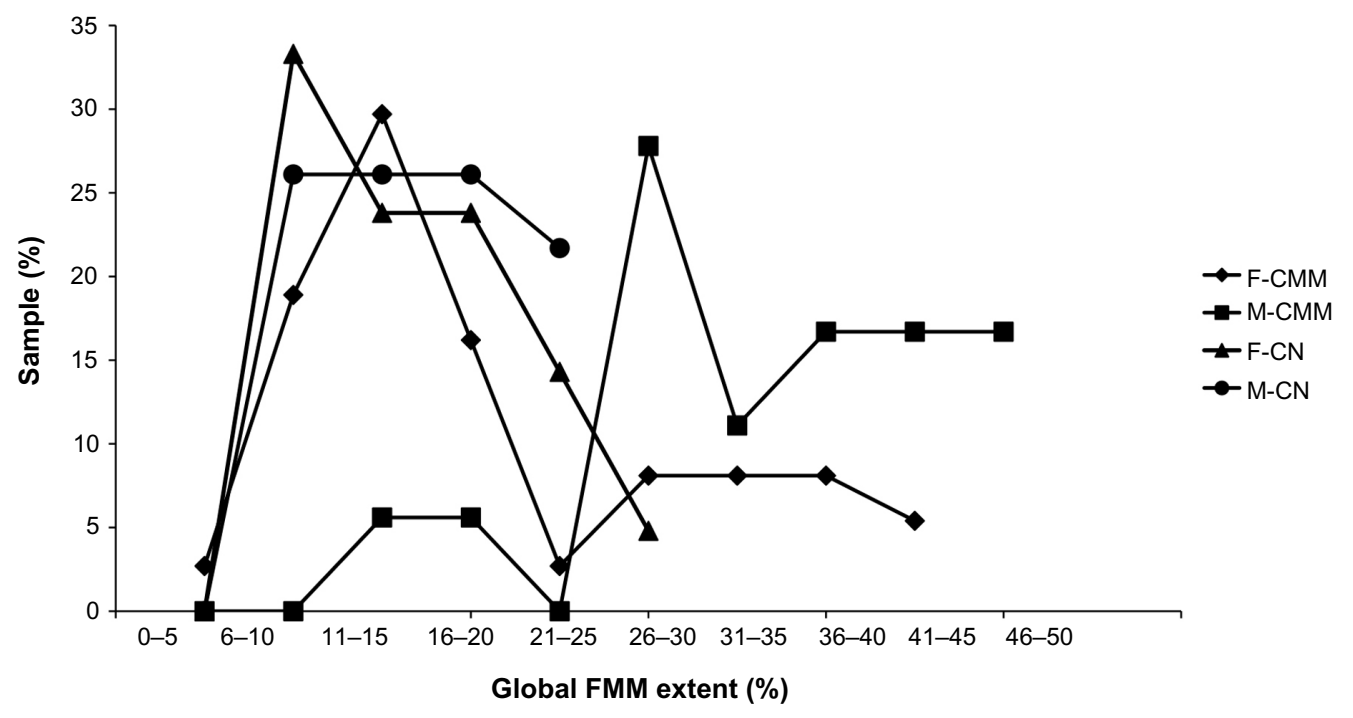

Figure 3 Distribution of patients (\%), according to the global extent of FMM in the peritumoral skin, in female and male young adults suffering from a thin CMM or a CN. Notes: The distributions were similar in subjects with CN and the majority of women with CMM. By contrast, most men with CMM showed higher FMM extent, as well as a minority of women with CMM.

Abbreviations: CMM, cutaneous malignant melanoma; CN, congenital melanocytic nevus; F, female; FMM, faint mosaic melanoderma; M, male. 
production of melanin suffer from a higher incidence of skin cancers. ${ }^{34}$ The relationship between the total melanin content, the eumelanin:pheomelanin ratio, and the activity of the key melanogenic enzyme, tyrosinase, is complex. ${ }^{35}$ Mature melanosomes filled with melanin pigment are transported from the melanocyte cell body into the dendrites to be transferred to the keratinocytes, where they localize to the uppermost perinuclear area. ${ }^{36}$ The transfer of melanosomes to keratinocytes is regulated by protease-activated receptor 2 (PAR2) and its peptide activator, SLIGRL. ${ }^{36}$

In the present study, the increased extent of FMM in a large proportion of young Caucasian men with CMM compared with controls probably indicated either an excessive chronic UVL exposure or an excessive innate skin response to casual UVL exposure. The proportion of CMM women showing a similar larger extent of FMM was less prominent than in men. Such finding might suggest that some female CMM might be coinduced by agents distinct from UVL.

The risk for developing CMM is influenced by the sex. ${ }^{1,37,38}$ Differences in sun exposure in the population ${ }^{24,28,39-41}$ might also be in part responsible. An effect of endocrine disruptors is possible $\mathrm{e}^{42-44}$ - these could interfere with estrogen receptors and alter the functions of some $H O X$ genes. ${ }^{45-47}$ It should be noted that the CMM lesions collected in the present study were thin and slow proliferative. This suggests that they represented a sampling of lesions following a benign clinical course, although they exhibited the histopathological features of CMM, corresponding to so-called nonmetastasizing CMM.

\section{Acknowledgments}

This work was supported in part by a grant from the "Fonds d'Investissement de la Recherche Scientifique" of the University Hospital of Liège. We thank the dermatologist members of the "Groupe Mosan d'Etude des Tumeurs Pigmentaires" who referred their surgical excisions of cutaneous malignant melanomas to our Dermatopathology laboratory. The authors appreciate the excellent data management and secretarial assistance of Mrs Ida Leclercq.

\section{Disclosure}

The authors report no conflicts of interest in this work.

\section{References}

1. Piérard-Franchimont C, Uhoda I, Piérard GE. Cutaneous cancers in the Mosan region and Ardennes of Belgium. Dermatology. 1999;198(2): 187-191.

2. Leiter U, Garbe C. Epidemiology of melanoma and nonmelanoma skin cancer - the role of sunlight. Adv Exp Med Biol. 2008;624:89-103.
3. Richards TB, Johnson CJ, Tatalovich Z, et al. Association between cutaneous melanoma incidence rates among white US residents and county-level estimates of solar ultraviolet exposure. JAm Acad Dermatol. 2011; 65(5 Suppl 1):S50-S57.

4. Boniol M, Autier P, Boyle P, Gandini S. Cutaneous melanoma attributable to sunbed use: systematic review and meta-analysis. $B M J$. 2012;345:e4757.

5. Little EG, Eide MJ. Update on the current state of melanoma incidence. Dermatol Clin. 2012;30(3):355-361.

6. Chen ST, Geller AC, Tsao H. Update on the Epidemiology of Melanoma. Curr Dermatol Rep. 2013;2(1):24-34.

7. Uhoda I, Quatresooz P, Fumal I, Nikkels AF, Piérard-Franchimont C, Piérard GE. Updating trends in cutaneous cancers in south-east Belgium. Oncol Rep. 2004;12(1):111-114.

8. Quatresooz P, Uhoda I, Fumal I, Piérard-Franchimont C, Piérard GE. Revisiting the gender-linked melanoma burden. Dermatology. 2004;209(3):197-201.

9. Reed KB, Brewer JD, Lohse CM, Bringe KE, Pruitt CN, Gibson LE. Increasing incidence of melanoma among young adults: an epidemiological study in Olmsted County, Minnesota. Mayo Clin Proc. 2012;87(4):328-334.

10. Siegel R, Naishadham D, Jemal A. Cancer statistics, 2012. CA Cancer J Clin. 2012;62(1):10-29.

11. Krause M, Klit A, Blomberg Jensen M, et al. Sunscreens: are they beneficial for health? An overview of endocrine disrupting properties of UV-filters. Int J Androl. 2012;35(3):424-436.

12. Birnbaum LS. State of the science of endocrine disruptors. Environ Health Perspect. 2013;121(4):A107.

13. Rylander L, Rignell-Hydbom A, Tinnerberg H, Jönsson BA. Trends in human concentrations of endocrine disruptors: possible reasons and consequences. J Epidemiol Community Health. 2014;68(1):4-5.

14. Nordlund JJ. The melanocyte and the epidermal melanin unit: an expanded concept. Dermatol Clin. 2007;25(3):271-281, vii.

15. Hermanns JF, Petit L, Martalo O, Piérard-Franchimont C, Cauwenbergh G, Piérard GE. Unraveling the patterns of subclinical pheomelaninenriched facial hyperpigmentation: effect of depigmenting agents. Dermatology. 2000;201(2):118-122.

16. Petit L, Fogouang L, Uhoda I, Smitz S, Piérard-Franchimont C, Piérard GE. Regional variability in mottled subclinical melanoderma in the elderly. Exp Gerontol. 2003;38(3):327-331.

17. Quatresooz P, Petit L, Uhoda I, Pierard-Franchimont C, Pierard GE. Mosaic subclinical melanoderma: an Achilles heel for UV-related epidermal carcinogenesis? Int J Oncol. 2004;25(6):1763-1767.

18. Szepetiuk G, Piérard S, Pierard-Franchimont C, Caucanas M, Quatresooz P, Pierard GE. Recent trends in specular light reflectance beyond clinical fluorescence diagnosis. Eur J Dermatol. 2011;21(2):157-161.

19. Piérard GE, Piérard-Franchimont C, Quatresooz P. Field melanin mapping of the hairless scalp. Skin Res Technol. 2012;18(4):431-435.

20. Hermanns-Lê T, Piérard-Franchimont C, Piérard GE. Scrutinizing skinfield melanin patterns in young Caucasian women. Expert Opin Med Diagn. 2013;7(5):455-462.

21. Quatresooz P, Piérard-Franchimont C, Piérard GE. The skin ivory spot. A possible indicator for skinfield photo-carcinogenesis in recreational sunbed addicts. Int J Environ Res Public Health. 2012;9(2):362-369.

22. Szepetiuk G, Piérard-Franchimont C, Quatresooz P, Piérard GE. [Physico-biological foundation of skin fluorescence - review]. Pathol Biol (Paris). 2012;60(6):380-386. French.

23. Quatresooz P, Pierard GE, Pierard-Franchimont C; Mosan Study Group of Pigmented Tumors. Molecular pathways supporting the proliferation staging of malignant melanoma (review). Int J Mol Med. 2009;24(3):295-301.

24. Kanavy HE, Gerstenblith MR. Ultraviolet radiation and melanoma. Semin Cutan Med Surg. 2011;30(4):222-228.

25. Maddodi N, Setaluri V. Role of UV in cutaneous melanoma. Photochem Photobiol. 2008;84(2):528-536.

26. Abdel-Malek ZA, Kadekaro AL, Swope VB. Stepping up melanocytes to the challenge of UV exposure. Pigment Cell Melanoma Res. 2010; 23(2):171-186. 
27. Narayanan DL, Saladi RN, Fox JL. Ultraviolet radiation and skin cancer. Int J Dermatol. 2010;49(9):978-986.

28. von Thaler AK, Kamenisch Y, Berneburg M. The role of ultraviolet radiation in melanomagenesis. Exp Dermatol. 2010;19(2):81-88.

29. Roesch A, Fukunaga-Kalabis M, Schmidt EC, et al. A temporarily distinct subpopulation of slow-cycling melanoma cells is required for continuous tumor growth. Cell. 2010;141(4):583-594.

30. Piérard GE. Cell proliferation in cutaneous malignant melanoma: relationship with neoplastic progression. ISRN Dermatol. 2012;2012: 828146.

31. Brenner M, Hearing VJ. The protective role of melanin against UV damage in human skin. Photochem Photobiol. 2008;84(3):539-549.

32. Quatresooz P, Xhauflaire-Uhoda E, Piérard-Franchimont C, Piérard GE. Epidermal field carcinogenesis in bald-headed: An attempt at finetuning early non-invasive detection. Oncol Rep. 2009;21(5):1313-1316.

33. Maddodi N, Jayanthy A, Setaluri V. Shining light on skin pigmentation: the darker and the brighter side of effects of UV radiation. Photochem Photobiol. 2012;88(5):1075-1082.

34. Asuquo ME, Ngim O, Ebughe G, Bassey EE. Skin cancers amongst four Nigerian albinos. Int J Dermatol. 2009;48(6):636-638.

35. Wakamatsu K, Kavanagh R, Kadekaro AL, et al. Diversity of pigmentation in cultured human melanocytes is due to differences in the type as well as quantity of melanin. Pigment Cell Res. 2006;19(2):154-162.

36. Seiberg M, Paine $\mathrm{C}$, Sharlow $\mathrm{E}$, et al. Inhibition of melanosome transfer results in skin lightening. J Invest Dermatol. 2000;115(2):162-167.

37. Hajdarevic S, Schmitt-Egenolf M, Brulin C, Sundbom E, Hörnsten A. Malignant melanoma: gender patterns in care seeking for suspect marks. J Clin Nurs. 2011;20(17-18):2676-2684.

38. Coups EJ, Heckman CJ, Manne SL. Melanoma risk and preventive behaviors among men and women. Am J Surg. 2012;204(4):551-552.
39. Schiller M, Brzoska T, Böhm M, et al. Solar-simulated ultraviolet radiation-induced upregulation of the melanocortin-1 receptor, proopiomelanocortin, and alpha-melanocyte-stimulating hormone in human epidermis in vivo. J Invest Dermatol. 2004;122(2):468-476.

40. Autier P, Doré JF, Eggermont AM, Coebergh JW. Epidemiological evidence that UVA radiation is involved in the genesis of cutaneous melanoma. Curr Opin Oncol. 2011;23(2):189-196.

41. Newton-Bishop JA, Chang YM, Elliott F, et al. Relationship between sun exposure and melanoma risk for tumours in different body sites in a large case-control study in a temperate climate. Eur J Cancer. 2011;47(5):732-741.

42. de Giorgi V, Gori A, Gandini S, et al. Oestrogen receptor beta and melanoma: a comparative study. Br J Dermatol. 2013;168(3): 513-519.

43. Gandini S, Iodice S, Koomen E, Di Pietro A, Sera F, Caini S. Hormonal and reproductive factors in relation to melanoma in women: current review and meta-analysis. Eur J Cancer. 2011;47(17):2607-2617.

44. Grassi M, Rizzo L, Farina A. Endocrine disruptors compounds, pharmaceuticals and personal care products in urban wastewater: implications for agricultural reuse and their removal by adsorption process. Environ Sci Pollut Res Int. 2013;20(6):3616-3628.

45. Doi T, Puri P, Bannigan J, Thompson J. HoxB2, HoxB4 and Alx4 genes are downregulated in the cadmium-induced omphalocele in the chick model. Pediatr Surg Int. 2010;26(10):1017-1023.

46. Nakagawa K, Lee MJ, Sasaki N, Hayashi C, Nishio H. Cadmium exposure induces expression of the HOXB8 gene in COS-7 cells. Toxicol In Vitro. 2008;22(6):1447-1451.

47. Piérard GE, Piérard-Franchimont C. HOX gene aberrant expression in skin melanoma: a review. J Skin Cancer. 2012;2012:707260.
Clinical, Cosmetic and Investigational Dermatology

\section{Publish your work in this journal}

Clinical, Cosmetic and Investigational Dermatology is an international, peer-reviewed, open access, online journal that focuses on the latest clinical and experimental research in all aspects of skin disease and cosmetic interventions. All areas of dermatology will be covered; contributions will be welcomed from all clinicians and

\section{Dovepress}

basic science researchers globally. This journal is indexed on CAS The manuscript management system is completely online and includes a very quick and fair peer-review system, which is all easy to use. Visit http://www.dovepress.com/testimonials.php to read real quotes from published authors. 